\title{
3. Bordering on Equality: Women Miners in North America
}

\author{
Laurie Mercier
}

\section{Introduction}

Mining has often been upheld as the most 'masculine' occupation, and as one that traditionally prevents women from entering it, be it in sixteenth century Peru or twenty-first century South Africa. As many scholars have demonstrated, these restrictions are historical and social in nature, constructed to limit women's employment and encourage their reproductive labour at particular points in time. Yet these have been enforced as if 'natural'. In Canada and the US, two decades - the 1940s and 1970s - offer exceptions in women's employment in mining and, therefore, some insights into how women and their advocates might dislodge gender barriers. The Second World War presented a labour shortage that forced governments, companies and unions to recruit women to fill critical mining positions. Later, North American feminist movements compelled governments to open up former male bastions such as mining through Equal Employment Opportunity (EEO) legislation.

This chapter explores the reactions of male employers and co-workers as women challenged barriers to mining work and how they found, kept or were terminated from employment. Structural and cultural resistance appeared unyielding. The questions raised by the chapter include: How did women overcome obstacles to their employment? How and at what times did companies and unions attempt to break down or sustain rigid ideas of gender roles? Why did the number of women miners not increase more substantially over the next several decades?

The title of the chapter signifies at least two kinds of borders. The physical border between nations (in this case the US and Canada) has not historically impeded the movement of capital and ideas about gender. Women in mining have also been positioned on the borders (or barriers) of a male-dominated occupation. Despite legislative efforts such as EEO, most women miners have been discouraged by entrenched cultural resistance to their employment, alongside economic factors including mechanisation, plant shutdowns and declining jobs. These examples from Canadian and US mining workplaces 
illuminate the difficulties in instituting gender equality, and this historical perspective may suggest some lessons or directions to how to overcome those inequalities in mining worldwide.

\section{Masculinity and Mining: Background}

Two important recent, comparative anthologies reveal that gender constructions of work, family and militancy have been central to the masculine world of mining; and that women have played a more critical role in mining enterprises and communities than previously understood. In Women Miners in Developing Countries: Pit Women and Others (2006), Kuntala Lahiri-Dutt and Martha Macintyre present a number of essays that focus on artisanal and small-scale mining (ASM). ASM traditionally employed larger numbers of women than large-scale mining; and these women combined their earnings from mining with agricultural subsistence activities. Even when women were excluded from digging underground, they played pivotal economic roles on the surface in transporting and processing the diggings.

With tremendous variety in the world's mining enterprises, how did the occupation become so singularly male-centric? In Gier and Mercier (2006), it is found that gender exclusions emerged at particular historical moments and were hardly uniform across the world. For example, women in precolonial Africa mined below and above ground, while in the precolonial Andes it was considered 'bad luck' for women to work underground although they were central to mining work. Global historical forces of colonialism or capitalism often altered customary gender roles in mining, limiting women's traditional rights over mineral wealth. Attitudes towards women and mining were uneven in industrial societies as well. For example, the British parliament officially prohibited women from underground work as early as in 1842, although women miners continued to work in some regional pits in the early twentieth century. Elsewhere in the British Empire, Indian women laboured in British-owned mines for a fraction of the wages paid to their male counterparts. And even in societies such as Japan, where gender roles were rigidly enforced, surprisingly, women continued to mine underground until the mid-twentieth century.

Despite the variety of places in the world and mining activities represented in these two mentioned works - from gold to coal to copper and tin-a clear pattern emerges that links women's lives across time and space: as the processes of globalisation have expanded into postcolonial spaces, mining has become more masculine. These works conclude that the position of women in mining declines as the operation becomes more capitalised, centralised and mechanised. Whether in Asia, Europe, the Americas or Africa, societies and employers 
normalised women's exclusion from working underground through an elaborate set of superstitions, beliefs, traditions, sexual metaphors and seemingly 'rational' justifications, which were enforced through legislation or cultural taboos (see Francaviglia 1998).

Since we know that ideas about gender roles are historically and socially constructed, we need to know when, why and how mining became particularly resistant to women working underground. Yao (2006) provides a fascinating glimpse of how the numbers of Chinese women in mining rose and fell with changing political and economic tides. Communist emphasis on equal rights ended Confucian gender restrictions, but after economic reforms, women in China have seen their share of mining employment decline since the 1990s. In the 1950s and 1960s women miners were glorified as 'Iron Girls', but in reality they still represented a minority of workers underground. Some high profile accidents in the 1980s led to the 1992 regulation called the 'Provision for the Protection of Working Women', which prohibited the employment of women underground. With a new emphasis on markets, women workers were seen as more expensive with their maternity leave provisions, and less reliable than men. As a result of these restrictions, Chinese women have moved figuratively underground, working illegally in mining activities and losing prior benefits.

This is but one example that clearly illustrates the vacillation of employers and the state in either embracing or rejecting women miners, almost always tied to structural conditions. Companies or nations saw their own interests tied with patriarchal male miners and reinforced gendered practices, although they alternately viewed women as assets or liabilities in an effort to control labour. Companies often encouraged marriage and constructed family housing in order to sustain a more docile workforce; at other times, they tried to limit the number of women in a mining camp. Although men came to mostly dominate mining, women's reproductive and domestic work were essential to the industry. As a US Women's Bureau study concluded in the 1920s, miners' wives were of 'peculiar industrial and economic importance' to keep miners in the region (Lahiri-Dutt and Macintyre 2006: 6). Moreover, women's waged and unwaged work played a critical role in the basic economy of the industry. Women created economic niches through direct relationships to mining in surface operations that admitted them-along with entry in brothels, taverns and cafes, households and other businesses that maintained male miners.

Since mining has historically excluded women from employment, much research has focused on ways that women, through their reproductive labour, supported the industry; and, in their militancy, helped male miners through strikes and other labour actions. Despite company hopes that they would 'settle' and make a more dependent male workforce, women often became the more militant community members in demanding better wages and living conditions. 
In fact women often manipulated prevailing gender assumptions to more effectively and physically assert the goals of labour strikes. Women took over when men were restricted from participating in public demonstrations through injunctions, or experienced military and police violence. Labour movements preserved the ideals of female domesticity and the male worker as the head of household, but women creatively exploited these assigned roles to pursue their own interests and their own forms of protests. Thomas Klubock (1998) found in Chile's El Teniente, for example, women used the 'family wage' ideal to claim rights to their husbands' wages and benefits as well as work with them to extract economic and social concessions from Kennecott Corporation.

Abundant examples from the world's mining communities reveal how women exaggerated gender claims in solidarity for what they viewed as family and community, not just union, efforts. As Janet Finn (1998) documents in Chuquicamata, Chile, when the company tried to crush a strike, groups of women hid lunch buckets and even seized and dressed strikebreakers in women's clothing to ridicule their lack of manhood in failing to support the strike.

In the process of supporting men's labour rights, women often came to contest the gendered rules for protest and question their own roles in unions, families and communities. Because these moments of protest often appeared as much about challenging patriarchy as capitalism, male miners and unions were not always supportive of women's independent militancy when they performed more traditional support roles during strikes. Despite women's proven critical role in labour action, male miners often 'ordered wives back to the kitchen', as June Nash (1979) discovered in her study of Bolivian tin communities. But women and men repeatedly struggled over and renegotiated those gender roles.

Some of the greatest but less visible struggles occurred when women sought access to the mines that would allow them the opportunity to earn livelihoods equal to those of men. A historical approach allows us to see how gender conceptions are fluid and intersect with other identities such as class, race, culture and nation, as we examine how a minority of women boldly asserted their economic and social rights to do 'men's' work.

\section{Women and Mining: North American Context}

Two types of women miners have drawn historical attention: the intrepid individual prospectors of different class backgrounds who prospected the Rocky Mountains West from New Mexico to the Yukon in the nineteenth and 
early twentieth centuries; and the women who laboured underground for family survival, almost always in small enterprises, primarily coal, rather than hard rock, and alongside husbands or fathers. ${ }^{1}$

Although these examples are noteworthy in the sense that they challenge the assumptions about women's underground mining work, they contribute to an exceptionalism that may hinder a closer look at the gendered structural exclusions in corporate mining, which has dominated the industry in North America since the late nineteenth century. Since we know that women have been employed in smaller mine operations, and legislation and custom even allowed them underground, particularly when working with family members, it seems to me that the chief question to pursue, then, is why women could not work in larger mining operations?

Mining has been part of a larger culture of masculinity that infused industrial work. From the late nineteenth through to the late twentieth centuries resourcebased industries - logging, mining, agriculture, fishing-distinguished the gendered and racialised character of work in the US and Canada. Even though women and coloured people worked in these industries or the service sectors that supported them, narratives of regional work reinforce the concept of a white, male 'wageworkers' frontier' (see Schwantes 1979, 1982, 1988). These occupations elicit images of tough, masculine outdoor work and independence. They have also resisted hiring women and certain ethnic groups except when labour demands overwhelmed the exclusionary rigid boundaries they erected. The white male breadwinner ideal and the reputed toughness of the work that supposedly discouraged women from employment often disintegrated when labour markets expanded, when families required multiple breadwinners, or when these 'rugged' jobs became seasonal and low-paid, which then made women and people of colour 'ideally suited' for the work.

Industries, unions and male workers perpetuated this social order that reinforced the belief that much industrial work required rugged masculinity. Unions and workers might preserve jobs for white men, but employers could resist improving conditions or providing adequate workers' compensation by exploiting stereotypes that rendered workers tough enough to handle the most dangerous conditions or too rootless and family-less to warrant companyprovided protections (Robbins 1986; Forestell 2006).

\footnotetext{
1 For example, Irish immigrant Nellie Cashman, through her lifetime, searched the Klondike of the Canadian Yukon and north of the Arctic Circle in Alaska for precious metals and gained fame as a philanthropist from her mining earnings (Chaput 1996). For the history of women mining entrepreneurs see Zanjani (1997). On women coal miners during the Great Depression and other periods, see Gúerin-Gonzalez (2006) and Moore (1996).
} 
Despite union gains in North America after the 1930s, many mining union leaders and rank-and-file workers continued to believe that the association of masculinity with militancy aided their cause. The International Union of Mine, Mill, and Smelter Workers (IUMMSW), which represented the US and Canadian non-ferrous miners and refiners; and the United Mine Workers (UMW), representing coal miners, championed masculinity in their iconography and rhetorical traditions to assert their fierce independence. The mining industry's contraction during the 1920s and 1930s also reinforced it as a male domain, but the sudden demand for labour beginning in 1940 upset gendered notions of work.

\section{Labour Expansion in the 1940s}

Even during the Second World War - when much of Canada and the US opened industrial jobs to women - company, government and union officials sought to preserve men's claims to traditional mining occupations. Montana's war manpower director, for example, claimed that the state needed 'men for the hard, heavy and unpleasant jobs' in mines, mills and woods 'where women cannot be used'. Anaconda Copper Mining Company and Mine Mill union officials agreed that mines, mills and smelters could not employ women because the work required strength and stamina. But physical prowess evidently was not the chief requisite because the company began recruiting retired and disabled men (MHSA 1943). Nancy Forestell (2006: 86-7) charts how gold mines in Ontario resisted hiring women even during the war labour shortages. In other mining centres companies supported hiring women with the understanding that they could free-up large numbers of men on the surface to work underground. But gold mining executives decided not to pursue female workers since the mines employed disabled male workers on the surface, maintaining the gender exclusivity of the industry.

The war years provide ample examples to illustrate the shifting ground of gendered and racialised work categories. In Anaconda, Montana, the Anaconda Company manipulated perceptions of difference to convince union representatives to allow women into its smelter. Appealing to racial prejudices, the management threatened to import African-Americans and Mexicans to fill the labour void, emphasising that they would prefer Anaconda women 'rather than Mexican boys', but the federal government could send 'coloured men' any time. Management and labour then agreed that they would preserve community values that championed white male and female breadwinners. The new employees had to be Anaconda residents, wives of former smelter workers in the service or recently deceased or disabled and with children or parents to support (Mercier 2001: 67-8). The conditions seemed clear; these women understood that they had to relinquish their positions to men at the war's end. 
Although the company never advertised the smelter openings in late 1943, word spread quickly and many women eagerly applied. The opportunity to earn men's wages was a powerful lure. Ursula Jurcich, strapped to care for an invalid husband and young son, noted that, 'Everybody was talking about it, "oh, the women are working on the [smelter] Hill." That was a big "baloo" around here ... so I thought I might as well go and see if I can get on ... the money was big, that was important' (personal communication, Ursula Jurcich, August 1986). Nonetheless, the company's ambivalence and the firm community male breadwinner ideal led to just over a hundred women hired on the smelter (compared to almost 400 men over 60 years in age) during the war.

Wartime labour demands, and the subsequent relaxation of occupational barriers, presented unprecedented opportunities for women of many ethnicities in various industries, especially new aircraft and shipbuilding plants. Mining remained off limits however, except to a small percentage of women who found work in processing ore and on surface operations. Since 1890, Ontario mining legislation had prohibited the employment of women in mines. Calling on the War Measures Act, the Canadian government issued an order on 13 August 1942 that allowed women to be employed to allay a labour shortage, but only for surface operations. At International Nickel's (Inco) Sudbury operations, over 1400 women were hired for production and maintenance jobs during the war. They performed a variety of jobs such as operating ore distributors, repairing cell flotation equipment, piloting ore trains and working in the machine shop. At the end of the war, the government rescinded the order allowing the employment of women in the company's surface operations, and Inco saved the positions for returning servicemen (Sudol 2008).

Why did urban shipyards and aircraft plants actively recruit women, while mining communities resisted hiring them (see John 1980; Mark-Lawson and Witz 1988; Kingsolver 1989)? Practices were influenced by well-entrenched gender ideologies, accompanying lore about the work and past union struggles for job security in automating industries. The industry's needs and economic position also explain the difference; the minerals industry had been declining except during the war boom, whereas new industries like shipbuilding demanded new recruits. This helps explain why women never constituted more than five per cent of the smelter workforce in Anaconda, while they made up 28 per cent of Portland, Oregon's shipyard workers (Skold 1980: 57; Kesselman 1990). ${ }^{2}$

Even the left-leaning labour union, the IUMMSW, wavered from its expressed goal of gender equality given male rank-and-file resistance. In Anaconda, when the company tried to bypass union seniority rules to give women 'soft'

2 In her study of women war workers, Karen Anderson (1981) concludes that labour markets, rather than community values, determined such variations. She notes, for example, that women made up just four per cent of Baltimore shipbuilders, compared to 16 per cent in Seattle, because of greater availability of black male workers in the East. 
positions, union leaders, struggling to preserve a male breadwinner workplace while maintaining labour principles, alternated between insisting that women be excluded as a weaker sex and that they be treated equally. By the end of the war, IUMMSW Local 117 sought to restore jobs to returning servicemen, but it also defended the women in a retroactive pay contractual issue. The union even sought to retain jobs for widows, who, as believed, merited continued employment because of their economic circumstances. But the union became caught in its own web of seniority rules, and the company insisted that the last woman hired would be the first to be laid off when a serviceman reclaimed his job. Within a few months no women were employed in production at the smelter. ${ }^{3}$ Pearl Chytuk, who moved to Sudbury, Ontario, from Regina, Saskatchewan, in 1941, was able to get a job at the Inco smelter during the war, but was surprised that people were fearful of talking about unions. While working at the smelter, Chytuk actively organised for Mine Mill Local 598. She remembered the hesitancy of some of her male co-workers, but many of the women activists were, 'from the west where we always felt more free'. Despite their activism, the union could not help them retain their jobs at the war's end (Solski and Smaller 1985: 124; Steedman et al. 1995: 162-5).

The postwar period brought a rapid resumption of restrictions, and old gender barriers were re-erected as men returned home to their jobs and women were discharged, underscoring the fluidity of these ideologies and how pinned to power relations they were. Nonetheless, women in mining communities were often fundamentally changed by their wartime experiences, as represented by married women's increasing participation in the labour force. For example, women who worked in the Anaconda smelter during the war lost their jobs, but the independence they tasted lasted in subsequent work and family roles. Erma Bennett recalled that after the war people 'tried to change it back', but it was 'the beginning of the change' in women's roles as they sought greater public and economic participation (Mercier 2001: 91). In single industry mining communities, well-paying mining and smelting jobs remained enticing (if forbidden) to women until legislation made opportunities available again.

\section{Labour Contraction in the 1970s}

If women received a frosty reception in the mining workplace during the wartime increase in labour demand, their efforts to re-enter mines and smelters several decades later following government and union mandates presented even more challenges in the light of a declining industry. In the US and Canada,

3 For an extended discussion of the women smelter workers and gendered debates about employment during and after the war, see Mercier (2001: 64-77). 
women won the legal right to enter male mining workplaces just as the industry began to mechanise, move operations out of the country and lay off workers in the 1970s. Federal affirmative action orders opened coal and hard-rock production jobs to women for the first time since the Second World War. For women in places like Arizona, Montana, Appalachia and Ontario, despite male resistance and harassment, the good wages offered made competition stiff for the few mining jobs available.

Despite initial opposition, female miners broke barriers in the UMW and created the Coal Employment Project (CEP) to combat discrimination, work on health and safety issues and form an international network of coalfield women. Although 1965 US Civil Rights legislation was amended in 1967 to include gender as a basis for non-discrimination, abolishing state prohibitions against women mining, social sanctions remained, as Carletta Savage (2000: 232) notes, 'in full force'. A class-action lawsuit settled in 1978 forced Appalachian coal companies to open their tunnels to women. In 1977 women made up just one per cent of the mining workforce; by 1979, they had increased to over 10 per cent (Moore 1996: xl-xlvi).

In the mid-1990s Suzanne Tallichet (2006) spent several months in a West Virginia coal mining community to uncover the world of women miners. In studying Bureau of Mines data the author found that gender was a more likely determinant of a miner's job rank than all other factors combined. In her research and interviews she determined that once hired, the 'daughters of the mountain' still had to negotiate tremendous barriers, including harassment from male co-workers and bosses and resistance from the community. Male miners asserted their solidarity and dominance by exaggerating gender differences and sexualising relationships with female co-workers. The interviewed women claimed that at least half of their co-workers and bosses targeted them with sexual and other harassment. To survive this treatment, more feared than the mine's dangers, women acted tough and repeatedly reminded the men of their practical needs: 'I'm not here for romance but for finance' (ibid.: 54). A woman had to prove her physical capabilities and accommodate men in various ways to win acceptance. ${ }^{4}$

But a 1981 CEP survey found that bosses, rather than co-workers, exacerbated women's problems underground. Tallichet (2006) and Savage's (2000) interviews with women miners confirmed that women were prevented from moving out of lower-paying strenuous jobs for more skilled positions. What was considered 'women's work' usually required the greatest physical endurance; supervisors rarely allowed women to learn new skills to operate machinery or they failed

4 Articles about women in mining frequently emphasise how the women had to show extraordinary stamina and good humour to survive male co-workers' bullying (see also, Sale 2007). 
to train them when they did attain those positions, which caused resentment among male co-workers who were frustrated by the women's inexperience. A decade after women entered coal mines in large numbers, they still lacked training, endured high rates of sexual harassment and with little training and seniority were the first to be laid off when the industry declined in the 1980s and 1990s. Savage (2000) concludes that the very paucity of information about gender relations available to supervisors and personnel departments in the coal industry reflects how insincere they were about successfully integrating women into the workforce. The small monetary awards from harassment and discrimination lawsuits, and the hard labour and physical and emotional decline convinced many women miners to leave the industry altogether.

Resistance to women's employment did not emerge solely from male miners and employers. A surprising theme emerges from all of these studies, whether hard rock or coal, US or Canadian mining communities: the resistance from miners' wives was often the most virulent, upending any notions of gender solidarity. Tallichet (2006) found in her interviews that the wives viewed women miners as sexual and economic threats. Many wives even believed that women were not physically suited to working underground, endangering their husbands' lives. This called into question who was entitled to a breadwinning wage. In 1974, miners' wives in Logan, West Virginia, protested a local mine's hiring of women. As Marat Moore (1996: xxxvii-viii) discovered, male miners voiced greater support for affirmative action quotas than did their wives. Women miners blamed the wives for hardening men's attitudes towards them underground. There is a striking racial difference here, however. Although black women faced even greater resistance to mining employment, they experienced support, rather than hostility, from men and women in their community. These findings remind us that we need to question universal notions about women.

Diminishing opportunities were even more apparent for women who had edged their way into hard rock mining. ${ }^{5}$ Jennifer Keck and Mary Powell (2006) outline how a hundred pioneering women took jobs at Inco in Sudbury, Ontario, in the mid-1970s after provincial legislation removed barriers to women's employment in surface jobs (1970) and later underground (1978). Motivated primarily by higher wages, women workers at Inco found that 'men's' jobs offered a great deal of satisfaction as well as greater financial independence. They endured the physically hard work, sexual harassment and difficulties finding child care to better support themselves and families. In adapting to masculine work culture, they had to prove they could 'do the work of a man' in order to be treated the 'same as a man'. In the process, they could achieve 'manhood' regardless of sex,

5 Although the coal industry also downsized and mechanised, reducing the numbers of workers, the oil and energy crises of the 1970s put more demand on production of domestic coal reserves, which sustained some demand for miners. 
breadwinner status based on family need and respect for fighting back. During the strike of 1978-79 women workers saw themselves as workers first and declined to join wives in making sandwiches, instead joining their brothers on the picket line and in negotiating committees. Yet these challenges to the gender division of labour became muted as the minerals industry restructured and downsized in the 1980s; women and minority workers with the least seniority were laid off first. ${ }^{6}$

In the tight-knit copper smelting community of Anaconda, women remembered their Second World War predecessors, and with EEO openings in the 1970s seized opportunities for higher pay. But community attitudes towards the new generation of women smelter workers were different in a climate of retrenchment. As former wartime smelter worker, Katie Dewing (personal communication, August 1996) recalled, the women who crossed gender boundaries 'the second time around' in the 1970s 'had hard jobs and did all the things that men do' because they 'were taking men's jobs'. Yet despite workforce reductions, the Anaconda Coal Mine made an earnest effort to implement EEO hiring. Personnel director Bob Vine insisted that the women 'were readily accepted' by male workers. This may be because few women lasted. In March 1974 Carolyn Crisler left her position as a nurse's aid to work at the smelter. Since she weighed less than the required 130 pounds, she slipped weights into her pants to get the job because 'we were trying to buy a house, and we needed the money, and I knew if I got up there, I could save a lot of money.' Despite the hot, dirty and dangerous work in the converters, Crisler 'liked the crew ... and the men accepted me and I did my work.' Nevertheless, she quit after two years because the physically exhausting work interfered with raising her young children. In 1980, the Atlantic Richfield Corporation, which absorbed the Montana ACM mines and smelters in 1977, shut down the state's operations.

The Arizona copper mining strike of 1983-85, involving the large multinational company, Phelps Dodge, and the Steelworkers Union represented a watershed moment in North American labour and mining history. Once again, women assumed a dominant role in maintaining the strike, loyally and passionately picketing for the same reasons they had in years past - to improve their families' living conditions, and to support striking men (and some women miners) who were legally enjoined from action. The strike ultimately failed and the company successfully decertified the union with its permanent replacement workers, ushering in a new non-union era in the American mining industry (Kingsolver 1989). Women miners and miners' wives in Arizona joined thousands of women

6 Gearhart (1998) notes that some women were displaced because of revived gender discrimination and the attraction of other work alternatives. 
from other declining mining communities in North America to find other wage work, often in the expanding service sector, and often became the main breadwinners in their families.

\section{Conclusion}

As these examples from North America and scholarship from around the world demonstrate, women have persistently sought access to mining jobs. Women miners endured discrimination, harassment and dangerous and demanding labour in order to gain more comfortable lives for their families and in many cases the self-satisfaction that they could perform a 'man's' job. These cases remind us how masculine work cultures, entrenched corporate practices and social assumptions about gender, even in periods of labour expansion (such as the Second World War) or structural legislative changes (as in the EEO push of the 1970s), can impede the entry and survival of women in the mining workplace.

By the 1970s coal and minerals companies and the United Mine Workers and Steelworkers Union (successor to Mine Mill) officially opposed discrimination and harassment, but the oral sources often contradict official pronouncements. By the 1980s, many women had formed an uneasy alliance with their male coworkers in mines and smelters. But automation and industrial decline forced layoffs, and having the least seniority, women made up a larger proportion of those terminated. Although men and women together faced uncertain futures, women had spent a decade proving themselves, only to see men hang on to the few remaining skilled mining jobs.

In the twenty-first century, the mobility of capital, government policies, global structural adjustment programs and the quality and exhaustibility of ore continue to threaten the stability of mining communities. Despite its often attractive wages, mining continues to disrupt women's and indigenous agricultural practices, cultural traditions and extended kin and community networks; it displaces communities, introduces diseases and pollutes lands and water. Once led to extract better wages and working conditions from mining companies, recent protests often attempt to keep mining out of an area or challenge the ways in which multinational corporations extract resources. Tibetan protests against Chinese mining, Australian protests of uranium production and Honduran, Sri Lankan, and Indonesian protests of US corporate mining reveal the growing 'cultures of solidarity' between women, environmentalists, indigenous peoples, mining communities and international human rights organisations. Since the 1990s, several international conferences involving women in mining countries 
have met and an International Women and Mining Network has formed to protest the unsustainable nature of mining and its harm to women and communities (see, for example, IWMN: 2010).

As others have noted, women have not shared the benefits of mining, and have borne a disproportionate share of mining's negative effects. Excluded from mining or denied skilled training, women are denied higher wages, and in their more informal mining activities are more subject to mercury pollution and other health hazards. While we explore the ways that transnational corporations, national and local governments and international institutions can integrate women more fully in mining jobs, we might also ask whether mining - by its very nature socially and environmentally disruptive - can ultimately sustain women and men and their communities. Even with gender equity, can there be more positive mining developments?

Although these examples from North America may not seem compatible with the experiences of women in the developing world, I think we can see how gender ideologies take root and spread across time, space and cultures. Understanding this process can perhaps lead us to find ways to help move women from the borders to the center of mining workplaces and the decision-making processes that affect their lives.

\section{References}

Anderson, K., 1981. Wartime Women: Sex Roles, Family Relations, and the Status of Women During World War II. Westport: Greenwood.

Chaput, D., 1996. 'In Search of Silver and Gold.' American History 30(6): 36-40.

Finn, J.L., 1998. Tracing the Veins: Of Copper, Culture, and Community from Butte to Chuquicamata. Berkeley: University of California Press.

Forestell, N.M., 2006. "And I Feel Like I'm Dying from Mining for Gold": Disability, Gender, and the Mining Community, 1920-1950.' Labor: Studies in Working Class History of the Americas 3(3): 77-93.

Francaviglia, R.V., 1998. 'In Her Image: Some Reflections on Gender and Power in the Mining Industry.' Mining History Journal 5: 118-26.

Gearhart, D.G., 1998. 'Coal Mining Women in the [American] West: The Realities of Difference in an Extreme Environment.' Journal of the West 37(1): 60-8.

Gier J. and L. Mercier (eds), 2006. Mining Women: Gender in the Development of a Global Industry, 1670 to 2005. New York: Palgrave Macmillan. 
Gendering the Field

Gúerin-Gonzalez, C., 2006. 'From Ludlow to Camp Solidarity: Women, Men, and Cultures of Solidarity in U.S. Coal Communities, 1912-1990.' In J. Gier and L. Mercier (eds), op. cit.

IWMN (International Women and Mining Network (RIMM)), 2010. 'Campaigns'. Viewed 5 September 2010 at http://www.rimmrights.org/campaigns.htm

John, A.V., 1980. By the Sweat of their Brow: Women Workers at Victorian Coal Mines. London: Croom Helm.

Keck, J. and M. Powell, 2006. 'Women into Mining Jobs at Inco: Challenging the Gender Division of Labor.' In J. Gier and L. Mercier (eds), op. cit.

Kesselman, A., 1990. Fleeting Opportunities: Women Shipyard Workers in Portland and Vancouver during World War II and Reconversion. Albany: State University of New York Press.

Kingsolver, B., 1989. Holding the Line: Women in the Great Arizona Mine Strike of 1983. New York: ILR Press.

Klubock, T.M., 1998. Contested Communities: Class, Gender, and Politics in Chile's El Teniente Copper Mine, 1904-1951. Durham: Duke University Press.

Lahiri-Dutt, K. and M. Macintyre (eds), 2006. Women Miners in Developing Countries: Pit Women and Others. Aldershot: Ashgate.

Mark-Lawson, J. and A. Witz, 1988. 'From "Family Labor" to "Family Wage"? The Case of Women's Labor in Nineteenth-Century Coalmining.' Social History 13: 151-74.

Mercier, L., 2001. Anaconda: Labor, Culture, and Community in Montana's Smelter City. Chicago: University of Illinois Press.

MHSA (Montana Historical Society Archives), 1943. 'Plant Manpower Analysis.' 62/3-1943. Viewed 5 September 2010 at http://montanahistoricalsociety.org/

Moore, M., 1996. Women in the Mines: Stories of Life and Work. New York: Twayne Publishers.

Nash, J., 1979. We Eat the Mines and the Mines Eat Us: Dependency and Exploitation in Bolivian Tin Mines. New York: Columbia University Press.

Robbins, W.G., 1986. 'Labor in the Pacific Slope Timber Industry: A TwentiethCentury Perspective.' Journal of the West 25(2): 8-13.

Sale, A., 2007. 'Sisters in Coal: A History of Women in the West Virginia Mines.' Goldenseal 33(1): 10-7. 
Savage, C., 2000. 'Re-gendering Coal: Female Miners and Male Supervisors.' Appalachian Journal 27(3): 232-48.

Schwantes, C.A., 1979. Radical Heritage: Labor, Socialism, and Reform in Washington and British Columbia, 1885-1917. Seattle: University of Washington Press.

, 1982. 'Protest in a Promised Land: Unemployment, Disinheritance and the Origin of Labor Militancy in the Pacific Northwest, 1885-86.' Western Historical Quarterly 13: 373-90.

- 1988. 'Images of the Wageworkers' Frontier.' Montana: The Magazine of Western History 38: 38-49.

Skold, K.B., 1980. 'The Job He Left Behind: American Women in the Shipyards During World War II.' In C.R. Berkin and C.M. Lovett (eds). Women, War, and Revolution. New York: Holmes \& Meier.

Solski, M. and J. Smaller, 1985. Mine Mill: The History of the IUMMSW in Canada since 1895. Ottawa: Steel Rail Publishing.

Steedman, M., P. Suschnigg and D.K. Buse (eds), 1995. Hard Lessons: The Mine Mill Union in the Canadian Labour Movement. Toronto: Dundurn Press.

Sudol, S., 2008. 'Inco's Sudbury Nickel Mines were Critical during World War Two.' Republic of Mining. Viewed 4 October 2008 at http://www. republicofmining.com/category/women-in-mining/

Tallichet, S.E., 2006. Daughters of the Mountain: Women Coal Miners in Central Appalachia. University Park, Pennsylvania: Pennsylvania State University Press.

Yao, L., 2006. 'Women in the Mining Industry of Contemporary China.' In Kuntala Lahiri-Dutt and M. Mcintyre (eds), op. cit.

Zanjani, S., 1997. A Mine of her Own: Women Prospectors in the American West, 1850-1950. Lincoln: University of Nebraska Press. 